\title{
PEMBELAJARAN BERBASIS MASALAH MENGGUNAKAN MEDIA VIDEO UNTUK MENINGKATKAN AKTIVITAS DAN PRESTASI BELAJAR EKONOMI
}

\author{
Tri Ismiyati \\ SMAN 1 Godean, Sleman, DIY \\ Email: ismiyatit@gmail.com
}

\begin{abstract}
Abstrak
Penelitian tindakan ini bertujuan meningkatkan aktivitas dan prestasi belajar ekonomi peserta didik kelas XI IPS2 SMA N 1 Godean. Metode pengumpulan data menggunakan wawancara, observasi, catatan lapangan, tes, dan dokumentasi. Teknik analisis data secara deskriptif kuantitatif. Hasil penelitian menunjukkan bahwa pembelajaran berbasis masalah menggunakan media video mampu meningkatkan aktivitas belajar dari skor rerata 70,7\% pada siklus I menjadi 77,6\% pada siklus II. Prestasi belajar ekonomi meningkat dari 70\% mencapai KKM pada siklus I menjadi 83\% pada siklus II. Dengan demikian, pembelajaran berbasis masalah menggunakan media video terbukti meningkatkan aktivitas dan prestasi belajar ekonomi peserta didik kelas XI IPS 2 SMA Negeri 1 Godean.
\end{abstract}

Kata kunci: pembelajaran berbasis masalah, media video, aktivitas belajar, prestasi belajar

\section{Latar Belakang}

Pada kurikulum 2013, pembelajaran ekonomi mencakup seluruh proses, mulai dari memahami konsep yang terkandung di dalamnya, memahami permasalahannya, dan menyelesaikan masalah sesuai dengan konsepnya. Di dalam Peraturan Menteri Pendidikan dan Kebudayaan Nomor 24 Tahun 2016 tentang KI dan KD menyebutkan pada mata pelajaran ekonomi kelas XI hampir seluruh Kompetensi Dasar, 8 dari 9 $\mathrm{KD}$, yang dipelajari menuntut peserta didik untuk dapat menganalisis dan memecahkan masalah ekonomi nyata yang berkaitan dengan kehidupan sehari-hari. Agar peserta didik dapat memecahkan masalah ekonomi nyata yang berkaitan dengan kehidupan sehari-hari maka peserta didik dalam pembelajaran perlu dilatih untuk memecahkan masalah agar kreativitas peserta didik terasah dan lebih aktif. Untuk menjawab permasalahan tersebut, diperlukan model pembelajaran yang memandang peserta didik sebagai organisme yang berkembang dan memiliki potensi.

Model pembelajaran yang dipilih hendaknya mampu memenuhi 3 aspek, yaitu membentuk sikap positif pada peserta didik, mengembangkan kecerdasan intelektual, dan mengembangkan ketrampilan peserta didik sesuai dengan kebutuhan. Ada berbagai macam model pembelajaran yang dapat diterapkan di sekolah. Salah satu model pembelajaran yang dapat digunakan untuk melatih mengembangkan sikap, pengetahuan, dan keterampilan dalam memecahkan masalah ekonomi dunia nyata adalah model pembelajaran berbasis masalah (problem-based learning).

Dari hasil observasi pembelajaran ekonomi di kelas XI IPS 2 SMA Negeri 1 Godean diketahui bahwa dalam pembelajaran ekonomi ada beberapa peserta didik yang terlihat pasif dalam pembelajaran. Skenario pembelajaran yang dibuat guru belum optimal memanfaatkan media pembelajaran dengan metode yang dapat membangkitkan aktivitas peserta didik. Kurangnya aktivitas peserta didik berdampak pada belum optimalnya hasil belajar, pada KD 3.1 baru 70\% yang mencapai KKM. Artinya ada $30 \%$ peserta didik yang belum tuntas karena belum mencapai KKM $=75$. Untuk memecahkan masalah dalam pembelajaran ekonomi tersebut maka penulis mengimplementasikan "Pembelajaran Berbasis Masalah Menggunakan Media Video untuk 
Meningkatkan Aktivitas dan Prestasi Belajar Ekonomi Peserta didik Kelas XI IPS 2 SMA Negeri 1 Godean".

\section{Model Pembelajaran Berbasis Masalah (PBL)}

Model pembelajaran berbasis masalah (PBL) dapat membuat peserta didik belajar melalui upaya penyelesaian permasalahan dunia nyata secara terstruktur untuk mengonstruksi pengetahuan peserta didik. Pembelajaran ini menuntut peserta didik untuk aktif melakukan penyelidikan dalam menyelesaikan permasalahan dan guru berperan sebagai fasilitator atau pembimbing (Ridwan Abdulah Sani, 2015: 127). Sedangkan menurut Naskah Model Pembelajaran: "Pembelajaran berbasis masalah (PBL) bertujuan merangsang peserta didik untuk belajar melalui berbagai permasalahan nyata dalam kehidupan seharihari dikaitkan dengan pengetahuan yang telah atau akan dipelajarinya" (Direktorat Pembinaan SMA, 2015: 11-12)

Pembelajaran berbasis masalah memiliki tiga tujuan yang saling berhubungan satu dengan lainnya, yakni: a) Keterampilan berpikir dan pemecahan masalah, b) Pemodelan peran orang dewasa, dan c) Pelajar yang otonom (Arends dalam T.G. Ratumanan, 2015: 254). Ada lima fase utama dalam penggunaan model pembelajaran PBL, yakni: 1) Orientasi peserta didik pada masalah, 2) Mengorganisasi peserta didik untuk belajar, 3) Membimbing penyelidikan individual dan kelompok, 4) Mengembangkan dan menyajikan hasil karya (artefak), 5) Menganalisis dan mengevaluasi proses pemecahan masalah (Arends dalam T.G. Ratumanan, 2015: 256-257)

\section{Media Video}

Media video telah banyak digunakan untuk berbagai keperluan mulai dari hiburan hingga pendidikan. Media ini dapat mengungkapkan objek dan peristiwa seperti keadaan yang sebenarnya. Perencanaan yang baik dalam menggunakan media pembelajaran video akan membaut proses komunikasi pembelajaran menjadi lebih efektif (Rayandra Asyhar, 2012: 74).
Pembelajaran dengan model PBL akan melibatkan peserta didik untuk belajar menyelesaikan masalah dunia nyata dan sekaligus belajar untuk mengetahui pengetahuan yang diperlukan. Untuk itu guru perlu membantu mengidentifikasi permasalahan atau mengajukan permasalahan kontekstual yang akan dikaji peserta didik dengan bantuan media video.

\section{Aktivitas Belajar}

Aktivitas belajar adalah aktivitas yang bersifat fisik maupun mental. Dalam proses belajar kedua aktivitas itu harus saling berkaitan. Paul B. Diedrich yang dikutip dalam Hanafiah (2010: 24) menyatakan, aktivitas belajar dibagi ke dalam delapan kelompok, yaitu: 1) Kegiatankegiatan visual (visual activities, 2) Kegiatankegiatan lisan (oral activities), 3) Kegiatankegiatan mendengarkan (listening activities), 4) Kegiatan-kegiatan menulis (writing activities), 5) Kegiatan-kegiatan menggambar (drawing activities), 6) Kegiatan-kegiatan motorik (motor activities), 7) Kegiatan-kegiatan mental (mental activities), dan 8) Kegiatan-kegiatan emosional (emotional activities), yaitu minat, membedakan, berani, tenang, merasa bosan dan gugup.

\section{Prestasi Belajar Ekonomi}

Nawawi menjelaskan tentang prestasi belajar yaitu tingkatan keberhasilan peserta didik mempelajari materi pelajaran di sekolah yang dinyatakan dalam bentuk skor yang diperoleh dari hasil tes, mengenai materi pelajaran yang disajikan (Oemar Hamalik, 2005: 60). Faktorfaktor yang mempengaruhi belajar peserta didik dapat dibedakan menjadi tiga macam, yakni: 1) Faktor internal; 2) Faktor eksternal, dan 3) Faktor pendekatan belajar (Muhibbin Syah, 2011: 129).

\section{Hubungan Antara Aktivitas dan Prestasi Belajar}

Proses belajar mengajar melibatkan peserta didik dan menuntut peserta didik untuk melakukan aktivitas belajar. Para peserta didik dituntut untuk mendengar, memperhatikan, mencerna pelajaran, dan mengerjakan tugas- 
tugas yang diberikan guru. Menurut Sardiman (2009: 97): "Dalam belajar sangat diperlukan adanya aktivitas, tanpa aktivitas, belajar tidak mungkin berlangsung dengan baik karena pada prinsipnya belajar adalah berbuat untuk mengubah tingkah laku menjadi melakukan tindakan (aktivitas)". Aktivitas di sini bersifat fisik dan mental, dalam kegiatan belajar kedua aktivitas ini harus selalu terkait. Kaitan antar keduanya akan membuahkan aktivitas belajar yang optimal.

\section{Tujuan Penelitian}

Untuk meningkatkan aktivitas dan prestasi belajar Ekonomi peserta didik kelas XI IPS 2 SMA Negeri 1 Godean melalui penerapan Model Pembelajaran Berbasis Masalah Menggunakan Media Video.

\section{Hipotesis Tindakan}

Berdasarkan kajian teori dapat disusun hipotesis tindakan sebagai petunjuk arah bagi penelitian yaitu: "Pembelajaran Berbasis Masalah Menggunakan Media Video dapat Meningkatkan Aktivitas dan Prestasi Belajar Ekonomi Peserta didik Kelas XI IPS 2 SMA Negeri 1 Godean"

\section{Metode Penelitian Tindakan}

Jenis penelitian adalah penelitian tindakan kelas (PTK). Menurut Suharsimi Arikunto (2008:16), desain penelitian ini terdiri atas siklus-siklus. Setiap siklus terdiri dari satu rangkaian kegiatan yang meliputi 4 (empat) tahapan, yaitu: (1) perencanaan, (2) pelaksanaan tindakan, (3) pengamatan, dan (4) refleksi.

Penelitian ini dilaksanakan di SMA Negeri 1 Godean Kelas XI IPS 2 pada tahun ajaran 2017/2018. Waktu penelitian dilaksanakan selama 4 bulan pada bulan September s.d. Desember 2017. Penelitian tindakan dilakukan pada minimal dua siklus. Tahap persiapan dilakukan dengan menyusun RPP langkahlangkah PBL, menyiapkan lembar kerja dan media video yang akan digunakan dalam pembelajaran, serta menyiapkan lembar observasi dan instrumen evaluasi berupa tes tertulis.
Teknik pengumpulan data dan instrumen penelitian yang digunakan adalah: 1) Tes Prestasi Belajar dengan instrumen tes tulis essay, 2) Observasi dengan instrumen berupa lembar observasi, dan 3) Wawancara dengan menggunakan instrumen pedoman wawancara. Teknik analisis data menggunakan analisis deskriptif kualitatif dan mengikuti tahaptahap dari Miles dan Huberman yang meliputi: 1) Reduksi Data, 2) Penyajian Data, dan 3) Penarikan Kesimpulan (Sugiyono, 2008: 337). Dalam penelitian ini, indikator keberhasilan keaktifan dapat dilihat dari pencapaian poinpoin yang tertera dalam lembar observasi. Untuk variabel aktivitas belajar, indikator keberhasilan apabila minimal $75 \%$ peserta didik kelas XI IPS 2 aktif selama proses pembelajaran. Sedangkan untuk variabel prestasi belajar peserta didik, indikator keberhasilan apabila minimal $80 \%$ peserta didik kelas XI IPS 2 mencapai nilai KKM (75).

\section{Hasil Penelitian}

\section{Pelaksanaan Tindakan Siklus I}

Pelaksanaan tindakan di kelas XI IPS 2 SMA Negeri 1 Godean Sleman pada siklus I dilaksanakan dalam dua kali pertemuan yaitu pada tanggal 27 September 2017 dan 3 Oktober 2017 dengan pokok materi berupa: 1) konsep-konsep ketenagakerjaan, dan 2) sistem pengupahan dan kesejahteraan tenaga kerja.

Hasil observasi terhadap guru dalam penerapan pembelajaran ekonomi melalui PBL dengan video pada siklus I sejak pendahuluan, kegiatan inti, dan penutup telah berjalan sesuai RPP yang telah disusun. Pada tahap pendahuluan guru telah menyiapkan peserta didik secara fisik dan psikis untuk memulai pembelajaran.

Pada kegiatan inti pembelajaran pertemuan 1 dan 2 guru telah melaksanakan tindakan sesuai dengan sintaks atau langkah-langkah PBL berbasis video, yaitu fase 1: pada saat membuka pelajaran guru telah memberikan apersepsi dengan mengaitkan topik yang ada dengan topik baru, menyampaikan tujuan pembelajaran yang akan dicapai termasuk memberikan motivasi belajar kepada peserta didik serta menginformasikan materi, guru 
mengajukan pertanyaan/permasalahan serta materi yang dikaitkan dengan keseharian peserta didik melalui media video. Fase 2: pengorganisasian kegiatan pembelajaran yaitu dengan memotivasi peserta didik untuk mengeksplorasi dan merumuskan pertanyaan terkait video yang diputar dan membentuk kelompok diskusi yang heterogen. Fase 3, yaitu guru terlihat membimbing peserta didik menyelesaikan permasalahan dalam lembar kerja dalam diskusi kelompok. Fase 4 menyuruh kelompok menuliskan hasil diskusi kelompok dan mempresentasikan hasil karya dari kelompok, memotivasi peserta didik agar tampil berani mengajukan pertanyaan maupun menanggapi pendapat dari kelompok lain. Fase 5 guru telah menganalisis dan mengklarifikasi hasil kerja kelompok dan memberi penghargaan pada kelompok yang baik dalam mengerjakan tugasnya dalam diskusi kelompok.

Penggunaan media video menarik, ditandai dengan perhatian peserta didik yang tertuju pada video pada saat diputar, media video sesuai dengan materi dalam RPP. Seluruh peserta didik aktif bekerjasama dalam kelompoknya dan kadang ada yang membagi tugas diantara anggota kelompok untuk mengerjakan soal ataupun presentasi. Peserta didik juga tidak segan meminta bimbingan saat diskusi kelompok apabila dirasa ada hal-hal dalam penyelesaian masalah yang belum bisa.

Pada kegiatan penutup, guru telah memberikan penguatan berupa kata-kata pujian seperti bagus, pintar, baik, hebat, cerdas dan memberikan tepuk tangan, acungan jempol, anggukan atau senyuman. Akan tetapi guru belum memberikan penguatan dengan membuat kesimpulan pada akhir pelajaran. Guru telah memberikan evaluasi berupa tes lisan atau tertulis pada setiap akhir pertemuan, mengawasi peserta didik dalam mengerjakan soal evaluasi.

Berdasarkan hasil pengamatan pada pelaksanaan siklus I dalam proses pembelajaran dapat disimpulkan bahwa guru sudah menerapkan model PBL menggunakan media video sehingga aktivitas peserta didik dalam pembelajaran terjadi peningkatan selama siklus I sebagai berikut.

Tabel 1. Sebaran Data Aktivitas Peserta Didik Siklus I

\begin{tabular}{llcc}
\hline \multirow{2}{*}{ No } & \multirow{2}{*}{ Indikator Keaktifan } & \multicolumn{2}{c}{ Jumlah peserta didik/persentase } \\
\cline { 3 - 4 } & & TM 1 Siklus I & TM 2 Siklus I \\
\hline 1 & Membaca/mengamati/mendengarkan & $23(77 \%)$ & $24(80 \%)$ \\
\hline 2 & Menulis/mengerjakan tugas Lembar Kerja & $21(70 \%)$ & $23(77 \%)$ \\
\hline 3 & Kegiatan presentasi & $22(73 \%)$ & $24(80 \%)$ \\
\hline 4 & Kegiatan berpendapat/bertanya & $15(50 \%)$ & $18(60 \%)$ \\
\hline 5 & Kegiatan memecahkan masalah & $21(70 \%)$ & $21(70 \%)$ \\
\hline & Rerata & $68 \%$ & $73,4 \%$ \\
\hline
\end{tabular}

Tabel 2. Sebaran Nilai Post Tes Siklus I

\begin{tabular}{lcccc}
\hline No & Rentangan & Kategori & Frekuensi & Persentase \\
\hline 1 & $86-100$ & Sangat baik & 9 & $30 \%$ \\
\hline 2 & $75-85$ & Baik & 12 & $40 \%$ \\
\hline 3 & $66-74$ & Cukup & 9 & $30 \%$ \\
\hline 4 & $0-65$ & Kurang & 0 & $0 \%$ \\
\hline Jumlah & & 30 & $100 \%$ \\
\hline Nilai terendah & & \multicolumn{3}{c}{73} \\
\hline Nilai tertinggi & & \multicolumn{3}{c}{$78,83 /$ Baik } \\
\hline Rata-Rata/ kategori
\end{tabular}


Untuk variabel aktivitas belajar, indikator keberhasilan apabila minimal $75 \%$ peserta didik kelas XI IPS 2 aktif selama proses pembelajaran. Pada siklus I pertemuan pertama baru $68 \%$ peserta didik yang aktif dan pada pertemuan kedua baru $73,4 \%$ yang aktif. Dapat disimpulkan aktivitas belajar pada siklus I belum mencapai indikator keberhasilan $75 \%$ sehingga harus dilanjutkan pada siklus II.

Pada akhir siklus I yaitu tanggal 3 Oktober 2017 dilakukan Post Tes untuk mengetahui Prestasi belajar peserta didik selama pertemuan 1 sampai 2. Data yang diperoleh berupa data kuantitatif hasil belajar peserta didik selama proses pembelajaran pada siklus I. Hasil belajar peserta didik disajikan dalam tabel 2.

Berdasarkan tabel 2 dapat dijelaskan bahwa, nilai tertinggi yang dicapai peserta didik yaitu 87 dan nilai terendah yaitu 73 . Nilai rata-rata hasil belajar peserta didik sebesar 78,83 yang termasuk kategori baik dengan rentangan skor 75 - 85. Secara individu tidak ada peserta didik dengan kategori kurang, kategori cukup berjumlah 9 peserta didik (30\%), baik berjumlah 12 peserta didik (40\%), dan sangat baik berjumlah 9 peserta didik (30\%).

Indikator keberhasilan secara klasikal yang dicapai peserta didik dapat dilihat pada tabel 3 sebagai berikut.

Tabel 3. Sebaran Frekuensi Ketuntasan Belajar Peserta didik Secara Klasikal

\begin{tabular}{llcc}
\hline No & Kategori & Frekuensi & Persentase \\
\hline 1 & Tuntas & 21 & $70 \%$ \\
\hline 2 & $\begin{array}{l}\text { Belum } \\
\text { Tuntas }\end{array}$ & 9 & $30 \%$ \\
\hline $\begin{array}{l}\text { Jumlah Peserta } \\
\text { didik }\end{array}$ & 30 & $100 \%$ \\
\hline
\end{tabular}

Berdasarkan tabel 3 dijelaskan bahwa jumlah peserta didik yang telah tuntas berjumlah $21(70 \%)$ peserta didik, sedangkan $9(30 \%)$ peserta didik belum tuntas. Jadi, belum tercapai ketuntasan hasil belajar secara klasikal yang ditetapkan $80 \%$ dari jumlah peserta didik.

\section{Refleksi dan Revisi Siklus I}

Refleksi bertujuan sebagai pedoman perbaikan bagi pelaksanaan tindakan selanjutnya dan lebih difokuskan pada permasalahan dan keberhasilan dalam meningkatkan aktivitas peserta didik pada pembelajaran ekonomi. Adapun hasil refleksi tersebut adalah sebagai berikut:

1. Pembelajaran pada siklus I secara umum belum berjalan secara optimal. Peserta didik belum mampu mengikuti model pembelajaran PBL karena belum terbiasa dan masih ada beberapa peserta didik yang kurang aktif dalam pembelajaran.

2. Guru sudah menyampaikan KD dan tujuan pembelajaran serta memberikan motivasi belajar kepada peserta didik tentang pentingnya mempelajari materi ketenagakerjaan, sehingga peserta didik terlihat lebih bersemangat.

3. Semua peserta didik memperhatikan pada saat guru menayangkan video yang relevan tentang masalah ketenagakerjaan yang diambil dari internet. Video tidak ditayangkan secara penuh, hanya diambil bagian yang relevan. Akan lebih baik apabila video dibuat sendiri.

4. Ketika pembelajaran berlangsung, guru meminta perhatian peserta didik pada tujuan dan topik diskusi. Namun masih ada peserta didik yang pasif selama proses pembelajaran.

5. Suasana pembelajaran terasa tidak tegang karena peserta didik aktif dalam penyelesaian masalah bersama temanteman sekelompoknya.

6. Guru telah memberikan penguatan dengan segera ketika peserta didik melaksanakan suatu tindakan, dan memberikan tepuk tangan setelah peserta didik selesai melakukan tugas ataupun menyajikan hasil kerja kelompok

Berdasarkan hasil refleksi yang telah diuraikan di atas menunjukkan adanya beberapa kendala yang menyebabkan pembelajaran belum maksimal. Untuk itu perlu adanya perbaikan untuk melaksanakan tindakan pada pertemuan siklus II, antara lain:

1. Melaksanakan kembali pembelajaran berbasis masalah agar peserta didik lebih 
terbiasa dengan model tersebut.

2. Guru lebih memotivasi peserta didik untuk lebih aktif dalam berdiskusi dan berani mempresentasikan hasil karya ataupun menanggapi kelompok lain.

3. Guru membuat dan mengedit video yang sesuai dengan materi.

4. Guru perlu memberikan bimbingan secara menyeluruh agar peserta didik lebih aktif melakukan penyelesaian masalah.

5. Menugaskan peserta didik untuk membaca materi pelajaran di rumah agar lebih siap dan memahami materi yang akan dipelajari di kelas.

\section{Pelaksanaan Tindakan Siklus II}

Pelaksanaan tindakan di kelas XI IPS 2 SMA Negeri 1 Godean Sleman pada siklus II dilaksanakan dalam dua kali pertemuan yaitu pada tanggal 4 Oktober dan 10 Oktober 2017, dengan pokok materi: 1) Pengertian, faktor penyebab, jenis, dan dampak pengangguran, 2) Angka ketenagakerjaan dan cara mengatasi pengangguran.

Hasil observasi atas tindakan pada siklus II, pada kegiatan pendahuluan guru pada pertemuan 1 sampai pertemuan 2, fase 1 : yaitu pada saat membuka pelajaran guru telah memberikan apersepsi dengan mengaitkan topik konsep ketenagakerjaan telah dipelajari pada siklus I dengan topik baru tentang pengangguran, menyampaikan tujuan pembelajaran yang akan dicapai termasuk memberikan motivasi belajar kepada peserta didik serta menginformasikan permasalahan melalui video tentang pengangguran yang dibuat dan diedit sendiri oleh guru. Fase 2: pengorganisasian kegiatan pembelajaran yaitu dengan memotivasi peserta didik untuk mengeksplorasi dan merumuskan pertanyaan terkait video yang diputar dan membentuk kelompok diskusi yang heterogen. Fase 3: Berdasar permasalahan yang ditayangkan melalui video, guru membimbing peserta didik menyelesaikan permasalahan dalam lembar kerja melalui langkah PBL pada diskusi secara berkelompok. Fase 4: Guru telah memotivasi peserta didik untuk menyajikan hasil dan mempresentasikan hasil karya kelompok, juga telah meminta peserta didik menanggapi atau mengajukan pertanyaan kepada pekerjaan peserta didik dari kelompok lain. Fase 5: guru telah memberikan klarifikasi jawaban peserta didik dan menganalisis hasil jawaban peserta didik, menyuruh peserta didik membuat catatan dan kesimpulan dari materi yang diajarkan.

Penggunaan media video pembelajaran menarik, ditandai dengan perhatian peserta didik yang tertuju pada video pembelajaran pada saat diputar, media video pembelajaran sesuai dengan materi di RPP. Peserta didik sudah bekerjasama dalam kelompok dan membuat laporan dari lembar kerja yang dikumpulkan setiap akhir pembelajaran. Guru telah memberikan penguatan berupa kata-kata pujian seperti bagus, pintar, baik, hebat, cerdas dan memberikan tepuk tangan, acungkan tangan, anggukan atau senyuman. Berdasarkan hasil pengamatan pada pelaksanaan siklus II dalam proses pembelajaran guru sudah menerapkan model PBL menggunakan media video.

Data keaktifan peserta didik dari catatan observer selama pembelajaran ekonomi pada siklus II ada pada tabel 4.

Pada siklus II telah tampak adanya peningkatan pemahaman konsep dan aktivitas dalam belajar ekonomi oleh peserta didik yang lebih maksimal. Hal ini terbukti dengan adanya peningkatan aktivitas dan prestasi belajar peserta didik. Hasil Post Tes selama Siklus II dilaksanakan setelah pertemuan kedua yaitu pada tanggal 10 Oktober 2017 yang tujuannya untuk mengetahui pemahaman peserta didik terhadap materi yang telah dipelajari. Data kuantitatif prestasi belajar peserta didik selama proses pembelajaran pada siklus II. Prestasi belajar peserta didik disajikan dalam tabel 5. 
Tabel 4. Sebaran Data Aktivitas Peserta Didik Siklus II

\begin{tabular}{|c|c|c|c|}
\hline \multirow{2}{*}{ No } & \multirow{2}{*}{ Indikator Keaktifan } & \multicolumn{2}{|c|}{ Jumlah Peserta Didik/Persentase } \\
\hline & & TM 1 Siklus II & TM 2 Siklus II \\
\hline 1 & Membaca/mengamati/ mendengarkan & $25(83 \%)$ & $26(87 \%)$ \\
\hline 2 & Menulis/mengerjakan Lembar Kerja & $23(77 \%)$ & $24(80 \%)$ \\
\hline 3 & Kegiatan presentasi & $24(80 \%)$ & $25(83 \%)$ \\
\hline 4 & Kegiatan berpendapat/ bertanya & $20(67 \%)$ & $22(73 \%)$ \\
\hline \multirow[t]{2}{*}{5} & Kegiatan memecahkan masalah & $22(73 \%)$ & $22(73 \%)$ \\
\hline & Rerata & $76 \%$ & $79,2 \%$ \\
\hline
\end{tabular}

Tabel 5. Sebaran Post Test Siklus II

\begin{tabular}{|c|c|c|c|c|}
\hline No & Rentangan & Kategori & Frekuensi & Persentase \\
\hline 1 & $83-100$ & Sangat baik & 12 & $40 \%$ \\
\hline 2 & $75-82$ & Baik & 13 & $43 \%$ \\
\hline 3 & $66-74$ & Cukup & 5 & $17 \%$ \\
\hline 4 & $0-65$ & Kurang & 0 & $0 \%$ \\
\hline \multicolumn{3}{|c|}{ Jumlah } & 30 & $100 \%$ \\
\hline \multicolumn{3}{|c|}{ Nilai terendah } & \multicolumn{2}{|c|}{74} \\
\hline \multicolumn{3}{|c|}{ Nilai tertinggi } & \multicolumn{2}{|c|}{94} \\
\hline \multicolumn{3}{|c|}{ Rata-Rata/kategori } & \multicolumn{2}{|c|}{ 81,9/baik } \\
\hline
\end{tabular}

Berdasarkan tabel 5 dapat dijelaskan bahwa nilai tertinggi yang dicapai peserta didik yaitu 94 dan nilai terendah yaitu 74 . Nilai rata-rata hasil belajar peserta didik sebesar 81,9 yang termasuk kategori baik dengan rentangan skor $75-85$. Secara individu tidak ada yang termasuk kategori kurang, kategori cukup berjumlah 5 peserta didik (17\%), kategori baik berjumlah 13 peserta didik (43\%), dan sangat baik berjumlah 12 peserta didik (40\%).

Indikator keberhasilan secara klasikal yang dicapai peserta didik dapat dilihat pada tabel sebagai berikut.

Tabel 6. Sebaran Frekuensi Ketuntasan Belajar Klasikal Siklus II

\begin{tabular}{llcc}
\hline No & Kategori & Frek & Persentase \\
\hline 1 & Tuntas & 25 & $83 \%$ \\
\hline 2 & Belum Tuntas & 5 & $17 \%$ \\
\hline Jumlah Peserta didik & 30 & $100 \%$ \\
\hline
\end{tabular}

Berdasarkan tabel 6 dijelaskan bahwa jumlah peserta didik yang telah tuntas berjumlah 25 peserta didik (83\%), sedangkan 5 peserta didik (17\%) belum tuntas. Jadi, telah tercapai ketuntasan hasil belajar secara klasikal yang ditetapkan $80 \%$ dari jumlah peserta didik mencapai KKM (75).

\section{Refleksi Siklus II}

Siklus II merupakan perbaikan dari pelaksanaan pembelajaran siklus I. Dari hasil observasi pelaksanaan diskusi pada Siklus II terjadi peningkatan di semua aspek, hal ini dipengaruhi oleh pelaksanaan hasil refleksi siklus I. Dengan menyadari bahwa keaktifan peserta didik masih kurang dalam diskusi kelompok, maka segera dilakukan langkah-langkah yang dapat memotivasi peserta didik, peningkatan rasa percaya diri untuk bertanya dan menanggapi atau presentasi, serta meningkatkan keaktifan peserta didik dalam kerja kelompok. Aktivitas peserta didik makin meningkat dengan tindakan guru pada siklus II pertemuan 1 sampai 2 yaitu menumbuhkan motivasi di awal pembelajaran dengan pemutaran video, kemudian melakukan kegiatan inti dengan diskusi agar peserta didik berpikir dan aktif berbagi dengan 
temannya dalam melakukan proses pemecahan masalah bisa berjalan sebagaimana mestinya. Selanjutnya pada akhir pembelajaran guru mengulangi dengan memberi evaluasi pada tiap pertemuan kemudian membuat kesimpulan bersama-sama dengan peserta didik dan menyampaikan materi yang akan datang. Penelitian tidak dilanjutkan ke siklus berikutnya karena pada siklus II telah mencapai indikator keberhasilan yang ditetapkan, yaitu aktivitas belajar peserta didik telah mencapai $>75 \%$ dan prestasi belajar peserta didik telah $>80 \%$ yang mencapai $\mathrm{KKM}=75$.

\section{Pembahasan}

Aktivitas belajar peserta didik pada pembelajaran ekonomi di kelas XI IPS 2 SMA Negeri 1 Godean melalui penerapan model PBL menggunakan media video berdasarkan observasi tindakan pada siklus I dan II menunjukkan adanya peningkatan aktivitas belajar. Dari uraian aktivitas peserta didik pada pelaksanaan tindakan di pembelajaran ekonomi yang menerapkan model PBL menggunakan media video dapat disimpulkan telah terjadi peningkatan rerata aktivitas peserta didik sejak pertemuan pertama siklus I (68\%), pertemuan kedua siklus II $(73,4 \%)$, pertemuan pertama pada siklus II $(76 \%)$, dan terakhir pada pertemuan kedua siklus II (79,2\%). Berdasar data tersebut, rerata skor aktivitas belajar peserta didik pada siklus I adalah 70,7\%. Pada siklus II rerata aktivitas peserta didik dalam pembelajaran ekonomi adalah 77,6\%. Dari hasil tersebut dapat dinyatakan penerapan model PBL menggunakan media video pada pembelajaran ekonomi di kelas XI IPS 2 telah berhasil meningkatkan aktivitas peserta didik dalam pembelajaran ekonomi.

Peserta didik yang mencapai KKM pada siklus I berjumlah 21 peserta didik $(70 \%)$ dan ratarata hasil belajar yaitu 78.83 dengan kategori baik. Tindakan siklus II mampu meningkatkan hasil belajar peserta didik yang mencapai KKM berjumlah 25 peserta didik ( $83 \%$ ) dan rata-rata hasil belajar yaitu 81,97 dengan kategori baik sehingga tidak dilanjutkan dengan tindakan siklus berikutnya.
Peningkatan prestasi belajar ini terjadi karena penerapan model pembelajaran berbasis masalah menggunakan media video pada awalnya terlebih dulu meningkatkan aktivitas belajar peserta didik dalam pembelajaran ekonomi, terutama aktivitas peserta didik dalam kegiatan mengamati dan mendengarkan. Dengan menggunakan media pembelajaran video, peserta didik lebih antusias untuk lebih memperhatikan, melihat, dan mendengarkan pada saat video diputar oleh guru pada awal kegiatan inti pembelajaran.

Aktivitas melihat dan mendengar tersebut, kemudian disusul dengan aktivitas-aktivitas lain dari peserta didik selama pembelajaran sehingga materi pembelajaran lebih dipahami. Karena materi pembelajaran lebih dipahami, maka prestasi belajar peserta didik meningkat. Hal ini ditunjukkan dari hasil rerata post test siklus II $(81,97)$ yang lebih tinggi dari rerata post test siklus I (78.83). Dapat dinyatakan, pembelajaran berbasis masalah menggunakan media video dapat meningkatkan aktivitas dan prestasi belajar peserta didik pada mata pelajaran ekonomi di SMA Negeri 1 Godean.

Peningkatan aktivitas dan prestasi belajar ini tidak lepas dari pembelajaran berbasis masalah menggunakan media video. Dalam pembelajaran dengan model PBL peserta didik dihadapkan pada masalah yang menuntut mereka berkolaborasi melakukan penemuan untuk pemecahan masalah. Guru dalam pembelajaran dengan model PBL berperan sebagai penyaji masalah, penanya, mengadakan dialog bimbingan dalam menyelesaikan masalah, dan juga menyiapkan dukungan yang dapat meningkatkan motivasi dan pertumbuhan daya pikir peserta didik.

\section{Tinjauan Kritis Pembelajaran Berbasis Masalah}

Model pembelajaran berbasis masalah menggunakan masalah sebagai pemicu untuk mencapai tujuan pembelajaran dalam kelompok belajar yang dilanjutkan proses pencarian informasi. Peserta didik dirangsang untuk mengeksplorasi masalah ketenagakerjaan dan 
pengangguran yang riil terjadi di masyarakat melalui video. Masalah yang disajikan merangsang peserta didik untuk berpikir kritis dan mencari bukti informasi yang relevan dengan pengetahuan/teori yang diperoleh yang kemudian diintegrasikan. Karena proses pembelajaran berbasis masalah dalam bentuk terbuka, maka guru berkewajiban mendesain masalah dengan struktur yang baik untuk mencapai tujuan pembelajaran. Pembelajaran berbasis masalah melatih peserta didik agar mampu berpikir kritis, komunikatif, dan berkolaborasi dalam kelompok.

\section{Simpulan dan Saran}

Dari hasil penelitian yang telah dilakukan dapat disimpulkan: Hasil penerapan model PBL menggunakan media video dapat meningkatkan aktivitas belajar ekonomi yang ditunjukkan dengan skor rata-rata pada siklus I adalah 70,7\% dan pada siklus II sebesar 77,6\%. Pencapaian tersebut telah melampaui indikator pencapaian aktivitas peserta didik yang telah ditetapkan sebanyak 75\%. Prestasi belajar ekonomi juga mengalami peningkatan dari siklus I sejumlah $70 \%$ peserta didik mencapai $\mathrm{KKM}=75$ dengan rata-rata nilai prestasi belajar 78,83 dan pada siklus II mampu meningkatkan prestasi belajar peserta didik yang mencapai $83 \%$ peserta didik mencapai KKM dengan rata-rata nilai prestasi belajar sebesar 81,97 .

Setelah dilakukan pembelajaran dengan model PBL berbasis video pada Siklus I dan Siklus II terjadi peningkatan yang signifikan atas perhatian dan keterlibatan peserta didik dalam pembelajaran. Peserta didik lebih termotivasi, pembelajaran lebih demokratis, lebih menyenangkan, dan aktivitas peserta didik dalam diskusi kelompok mengalami peningkatan sehingga berpengaruh terhadap peningkatan prestasi belajar peserta didik.

Berdasarkan simpulan yang telah dipaparkan, ada beberapa saran yang dapat diajukan dari penelitian ini yaitu:

1. Untuk penelitian lebih lanjut:

Penelitian serupa perlu diadakan di sekolah lain dan pada mata pelajaran lain, dengan lingkup kajian yang lebih luas, sehingga dapat diketahui cara-cara lain yang lebih efektif untuk peningkatan kualitas pembelajaran.

2. Bagi Guru Ekonomi:

Perlunya para guru ekonomi untuk selalu meningkatkan diri antara lain menerapkan PBL dengan video yang merupakan model pembelajaran yang aktif, inovatif, dan menyenangkan dapat digunakan untuk meningkatkan aktivitas maupun prestasi belajar ekonomi peserta didik.

3. Bagi sekolah:

Sekolah menyediakan sarana yang memadai dan menyelenggarakan pelatihan model pembelajaran PBL dan model pembelajaran lain bagi para guru.

\section{Daftar Rujukan}

Hanafiah \& Suhana. (2010). Konsep Strategi Pembelajaran. Bandung: PT Refika Aditama.

Muhibbin Syah. (2011). Psikologi Pendidikan dengan Pendekatan Baru. Bandung: PT Remaja Rosdakarya.

Oemar Hamalik. (2005). Proses Belajar Mengajar. Jakarta: Bumi Aksara.

Rayandra Asyhar. (2012). Kreatif Mengembangkan Media Pembelajaran. Jakarta: Referensi.

Ridwan Abdulah Sani. (2015). Pembelajaran Saintifik. Untuk Implementasi Kurikulum 2013. Jakarta: Bumi Aksara.

Sardiman. (2009). Interaksi dan Motivasi Belajar Mengajar. Jakarta: Raja Grafindo Persada.

Sugiyono. (2008). Metode Penelitian Pendidikan, Pendekatan Kuantitatif, Kualitatif dan R\&D. Bandung: CV Alfabeta.

Suharsimi Arikunto. (2008). Penelitian Tindakan Kelas. Bandung: Bumi Aksara.

T.G. Ratumanan. (2015). Inovasi Pembelajaran. Yogyakarta: Ombak. 